\title{
PRELIMINARY ANTIPROLIFERATIVE EVALUATION OF NATURAL,-SYNTHETIC BENZALDEHYDES AND BENZYL ALCOHOLS
}

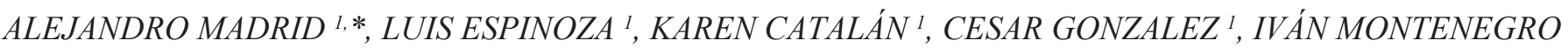 \\ ${ }^{1}$, MARCO MELLADO ${ }^{1}$,ENRIQUE WERNER ${ }^{2}$, MAURICIO CUELLAR ${ }^{3}$ AND JOAN VILLENA ${ }^{4, *}$
}

\author{
${ }^{\perp}$ Departamento de Química, Universidad Técnica Federico Santa María, Av. España $N^{\circ} 1680$, Valparaíso, Chile. \\ ${ }^{2}$ Departamento de Ciencias Básicas, Campus Fernando May Universidad del Bío-Bio, Avda.Andres Bello s/n casilla 447, Chillán, Chile. \\ ${ }^{3}$ Facultad de Farmacia, Universidad de Valparaiso, Av. Gran Bretaña $N^{\circ} 1093$, Valparaíso, Chile. \\ ${ }^{4}$ Centro de Investigaciones Biomédicas (CIB), Escuela de Medicina, Universidad de Valparaíso, Av. Hontaneda N ${ }^{\circ} 2664$, Valparaíso, Chile.
}

(Received: January 7, 2013 - Accepted: March 8, 2013)

\begin{abstract}
Vanillin, $o$-vanillin, natural and synthetic benzaldehydes and benzyl alcohols were assessed for antiproliferative effects using different human cell lines. Benzyl alcohols were synthesized from benzaldehydes reduced with $\mathrm{NaBH}_{4}$ in methanol solution. A new method for deprotection of ether compounds with TiCl solution was achieved with better performance, than previously reported. Twenty four compounds were tested. The in vitro growth inhibition assay was based on sulphorhodamine dye to quantify cell viability. Catechol $\mathbf{9}$ derived from piperonal as well as compounds $\mathbf{4}$ and $\mathbf{1 2}$ showed higher cytotoxicity on breast and prostate cancer cell lines (MDA-MB-231 and PC-3 respectively). $o$-Vanillin 5 has the highest cytotoxicity for all cell lines. $\mathrm{IC}_{50}$ values of $35.40 \pm 4.2 \mu \mathrm{M}$ Breast MDA-MB231; $47.10 \pm 3.8 \mu$ M Prostate PC-3; $72.50+5.4 \mu$ M Prostate DU-145; $85.10 \pm 6.5 \mu$ M and Colon HT-29, were obtained without toxicity towards dermal human fibroblast (DHF cells).
\end{abstract}

Key words: Antiproliferative; Benzaldehydes; Benzyl Alcohols; o-vainillin.

\section{INTRODUCTION}

Methoxybenzaldehydes effect over cancer cells has been reported, vanillin (4-hydroxy-3 methoxybenzaldehyde) exhibits a potent anti-proliferative effect on a broad spectrum of cancer cell lines. In 1986, Ohta et al. first tested the anti-mutagenic effect of vanillin on bacteria and found that vanillin could reduce 4-nitroquinoline-1-oxide ${ }^{1}$. Another compound from this family is anisaldehyde, which exhibits a concentration dependent cytotoxicity against murine B16 melanoma cells ${ }^{2}$. Another in vitro study has demonstrated inhibitor effect on hemoglobin $\mathrm{S}$ polymerization, of isovanillin, $o$-vainillin, $m$-hydroxybenzaldehide and the $p$-hydroxybenzaldehyde ${ }^{3}$.

It was reported by King et al., that vanillin is effective on the repair of mutations in colon cancer cells line HCT-116, this essay suggests colon cancer cells to be suitable for studying vanillin anti-mutagenic effect and its cytotoxicity relationship ${ }^{4}$. On the other hand, in 2002 da Silva et al. have reported that vanillin inhibits spontaneous mutation in bacteria ${ }^{5}$. Studies in Drosophila showed that vanillin inhibited mitomycin C-induced mutations and dramatically increases recombinations ${ }^{6}$, demonstrating that vanillin is a modifying factor that blocks the mutagenic pathway, and consequently directs the mitomycin-induced lesions into a recombinational repair. Other experimental tests suggested that post-treatment with vanillin protects against point mutations and chromosome aberrations induced by chemical and physical

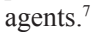

The purpose of the present work is to examine the effect of a series of 24 compounds related with benzaldehydes and benzyl alcohols. These compounds were tested on one human tumor breast cancer cell line (MDA-MB-231), one human colorectal cancer cell line (HT-29), two human prostate cancer cell lines (PC-3, DU-145), and one dermal human fibroblast cell line (DHF).

\section{EXPERIMENTAL SECTION}

\section{General}

Unless otherwise stated, all chemical reagents purchased (Merck or Aldrich) were of the highest commercially available purity and were used without previous purification. IR spectra were recorded as thin films in a FT-IR Nicolet 6700 spectrometer and frequencies are reported in $\mathrm{cm}^{-1}$. Low resolution mass spectra were recorded on an Agilent 5973 spectrometer at $70 \mathrm{eV}$ ionising voltage in a DB- $5 \mathrm{~m}, 30 \mathrm{~m} \times 0.25 \mathrm{~mm} \times 0.25 \mathrm{um}$ column, and dates are given as $\mathrm{m} / \mathrm{z}$ (\% rel. int.). ${ }^{1} \mathrm{H},{ }^{13} \mathrm{C},{ }^{13} \mathrm{C}$ DEPT-135, sel. gs $1 \mathrm{D}{ }^{1} \mathrm{H}$ NOESY, gs $2 \mathrm{D}$ HSQC and gs $2 \mathrm{D}$ HMBC spectra were recorded in $\mathrm{CDCl}_{3}$ solutions and are referenced to the residual peaks of $\mathrm{CHCl}_{3}$ at $\delta=7.26 \mathrm{ppm}$ and $\delta=77.0 \mathrm{ppm}$ for ${ }^{1} \mathrm{H}$ and ${ }^{13} \mathrm{C}$, respectively, on a Bruker Avance 400 Digital NMR spectrometer, operating at $400.1 \mathrm{MHz}$ for ${ }^{1} \mathrm{H}$ and $100.6 \mathrm{MHz}$ for ${ }^{13} \mathrm{C}$.
Chemicals

The natural and synthetic benzaldehydes were purchased from SigmaAldrich (St. Louis, MO, USA). All other chemicals (reagents and solvents) were obtained from Merck (Darmstadt, Germany) or Sigma-Aldrich (St. Louis, MO, USA).

\section{General procedure for the reduction of benzaldehydes}

All benzaldehydes were reduced using the method developed by Brown ${ }^{8}$ was slightly modified in this synthesis. A solution of piperonal $7(300.0 \mathrm{mg}, 2.0$ $\mathrm{mmol})$ in methanol $(50 \mathrm{~mL})$, sodium borohydride $(176.0 \mathrm{mg}, 4.65 \mathrm{mmol})$ was added in small portions and carefully. The reaction mixture was stirred at -10 ${ }^{\circ} \mathrm{C}$ for $2 \mathrm{~h}$. After work-up as in the reduction of alcohols, the resulting residue was recrystallized from hexane to give a tan solid identified as compound $\mathbf{2 2}$ (188.8 mg, $68.4 \%$ ); m.p.: 52.3-54.5 ${ }^{\circ} \mathrm{C}$. IR $\left(\mathrm{cm}^{-1}\right): 3349(\mathrm{O}-\mathrm{H}) ; 2918$ (C-H); $1610(\mathrm{C}=\mathrm{C}) ; 1432\left(-\mathrm{CH}_{2}\right) ; 815(-\mathrm{C}-\mathrm{H}) .{ }^{1} \mathrm{H}-\mathrm{NMR}: 6.86(\mathrm{~s}, 1 \mathrm{H}, \mathrm{H}-3) ; 6.79(\mathrm{~m}$, $2 \mathrm{H}, \mathrm{H}-5$ and $\mathrm{H}-6) ; 5.95\left(\mathrm{~s}, 2 \mathrm{H}, \mathrm{OCH}_{2} \mathrm{O}\right) ; 4.57\left(\mathrm{~s}, 2 \mathrm{H}, \mathrm{CH}_{2} \mathrm{OH}\right) ; 1.77(\mathrm{~s}, 1 \mathrm{H}$, OH). ${ }^{13} \mathrm{C}-\mathrm{NMR}$ : 148.5 (C-2); 147.5 (C-1); 133.7 (C-4); 118.6 (C-5); 109.8 (C6); 108.4 (C-3); $101.1\left(\mathrm{OCH}_{2} \mathrm{O}\right) ; 63.8\left(\underline{\mathrm{CH}}_{2} \mathrm{OH}\right)$.

General procedure for acetylation and methylation of benzaldehydes and benzyl alcohols.

Acetylation and methylation of benzaldehydes and benzyl alcohols of this work were used typical protocols in synthesis organic ${ }^{9}$.

\section{Procedure for the cleavage with $\mathrm{TiCl}_{\text {s }}$ solution}

The new method of synthesis consisted of a $\mathrm{TiCl}_{4}$ solution $(0.9 \mathrm{~mL}, 8.20$ $\mathrm{mmol}$ ) cooled to $-20^{\circ} \mathrm{C}$, was slowly added to a solution of piperonal $7(300 \mathrm{mg}$, $2 \mathrm{mmol})$ in $\mathrm{CH}_{2} \mathrm{Cl}_{2}(20 \mathrm{~mL})$ at $-10{ }^{\circ} \mathrm{C}$ under an atmosphere of $\mathrm{N}_{2}$ with gentle stirring. The reaction was continued for $4 \mathrm{~h}$ at $-20^{\circ} \mathrm{C}$. After this, the mixture was taken up in water and then extracted with ethyl acetate $(3 \times 50 \mathrm{~mL})$. The watery layer was discarded and the organic layer was washed to neutrality with a saturated solution of $\mathrm{NaHCO}_{3}$. The organic layer was dried over $\mathrm{MgSO}_{4}$, filtered and evaporated. Then it was absorbed on silica, chromatographed by $\mathrm{CC}$ eluting with mixtures of petroleum ether/EtOAc increasing polarity $(19.0: 1.0 \rightarrow 13.0: 7.0)$ to obtain a white solid identified as compound 9 (188.8 mg, $68.4 \%$ \%); m.p.: $149.8-150.8{ }^{\circ} \mathrm{C}$. IR $\left(\mathrm{cm}^{-1}\right): 3329(\mathrm{O}-\mathrm{H}) ; 2916$ (C-H); $(\mathrm{C}=\mathrm{O}) ; 1616(\mathrm{C}=\mathrm{C}) ; 1430\left(-\mathrm{CH}_{2}\right) ; 809(-\mathrm{C}-\mathrm{H}) .{ }^{1} \mathrm{H}-\mathrm{NMR}: 9.81(\mathrm{~s}, 1 \mathrm{H}, \mathrm{CHO})$; 7.49 (b.s., $1 \mathrm{H}, \mathrm{OH}) ; 7.44$ (b.s., $1 \mathrm{H}, \mathrm{OH}) ; 7.41$ (dd, $1 \mathrm{H}, J=8.1,1.2 \mathrm{~Hz}, \mathrm{H}-5)$; 7.28 (s, 1H, H-3); 6.73 (d, 1H, $J=7.9 \mathrm{~Hz}, \mathrm{H}-6) \cdot{ }^{13} \mathrm{C}-\mathrm{NMR}: 190.8$ (CHO); 151.9 (C-1); 145.6 (C-2); 129.2 (C-4); 121.5 (C-5); 115.5 (C-6); 114.6 (C-3).

\section{Cell Lines}

The experimental cell cultures were obtained from American Type Culture Collection (Rockville, MD, USA). All cancer cell lines were grown 
in DMEM-F12 medium containing 10\% FCS, $100 \mathrm{U} / \mathrm{mL}$ penicillin, $100 \mu \mathrm{g} /$ $\mathrm{mL}$ streptomycin and $1 \mathrm{mM}$ glutamine. Cells are seeded into 96 well microtiter plates in $100 \mu \mathrm{L}$ at plating density of $3 \times 10^{3}$ cells/well. After $24 \mathrm{~h}$ incubation at $37^{\circ} \mathrm{C}$ (under a $5 \%$ humidified carbon dioxide to allow cell attachment) the cells were treated with different concentrations of drugs (aldehydes and derivatives) and incubated for $72 \mathrm{~h}$ under the same conditions. Stock solution of compounds was prepared in ethanol and the final concentration of this solvent was kept constant at $0.1 \%$. Control cultures received only $0.1 \%$ ethanol.

\section{In vitro Growth Inhibition Assay}

The sulforhodamine B assay according to the method of Skehan et al. ${ }^{10}$ was used with some modifications ${ }^{11}$. Briefly, the cells were set up as $3 \times$ $10^{3}$ cells per well of a 96-well, flat-bottomed $200 \mu \mathrm{L}$ microplate. Cells were incubated at $37{ }^{\circ} \mathrm{C}$ in a $5 \%$ humidified $\mathrm{CO}_{2}$ plus $95 \%$ air mixture and treated with the compounds at different concentrations for 72 hours. At the end of drug exposure, cells were fixed with $50 \%$ trichloroacetic acid at $4{ }^{\circ} \mathrm{C}$ (TCA final concentration $10 \%)$. After washing with destilled water, cells were stained with $0.1 \%$ sulforhodamine B (Sigma-Aldrich, St. Louis, MO, USA), dissolved in $1 \%$ acetic acid $(50 \mu \mathrm{L} /$ well) for $30 \mathrm{~min}$, and subsequently washed with $1 \%$ acetic acid to remove unbound stain. Protein-bound stain was solubilized with $100 \mu \mathrm{L}$ of $10 \mathrm{mM}$ unbuffered Tris base. The cell density was determined using a fluorescence plate reader (wavelength $540 \mathrm{~nm}$ ). Values shown are the mean \pm SD three independent experiments in triplícate. Untreated cells were used as a negative control while, cells treated with doxorubicin were used as a positive control.

\section{RESULTS AND DISCUSSION}

\section{Chemistry}

All benzaldehydes were reduced using $\mathrm{NaBH}_{4}$ in methanol solution obtaining $^{8}$ the corresponding benzyl alcohols with almost 100 percent yield, the high reduction performance was achieved by the only in those compounds which showed no free hydroxyl as case of piperonal (Scheme 1), whereas in those molecules with a free hydroxyl as vanillin yield decreased to a half, and for molecules bearing two or more free hydroxyl groups yield decreased in about $20 \%$. Based on the low reduction yields, other methods such as $\mathrm{LiAlH}_{4}$ or zinc in acid media were tested to increase efficiency, for aldehydes with two or more hydroxyl groups, but with both methods the yields remained low; to solve this problem, molecules were subjected to reactions of methylation and acetylation, to block the free hydroxyl, and thus increase the benzyl alcohol yield close to $100 \%$, (Scheme 1). All the compounds were characterized by NMR, IR and MS spectral data and their structures were confirmed by comparison with spectral data in literature.<smiles>COc1cc(CO)ccc1Oc1cc(C(=O)NCCO)ccc1OC</smiles><smiles>CC(C)NC(=O)c1ccc(O)c(O)c1</smiles>

Scheme 1. General scheme of synthesis of Benzaldehydes derivatives

Conditions and reagents: a. $\mathrm{NaBH}_{4}, \mathrm{MeOH},-10{ }^{\circ} \mathrm{C}, 4 \mathrm{~h}, \mathbf{2 2} ; 95.1 \%$; 21 ; $92.3 \%$. b. i) $\mathrm{TiCl}_{4} / \mathrm{CH}_{2} \mathrm{Cl}_{2} ; \mathrm{N}_{2},-20^{\circ} \mathrm{C}, 4$ h iii) $\mathrm{H}_{2} \mathrm{O}$, r.t, $20 \mathrm{~h} ; \mathbf{9} ; 68.4 \%$.c. $\mathrm{Ac}_{2} \mathrm{O}$, DMAP, $\mathrm{CH}_{2} \mathrm{Cl}_{2}, 2$ h, r.t.; $25 ; 98.1 \%$. d. i) $\mathrm{NaBH}_{4}, \mathrm{MeOH}, 4$ h $-10^{\circ} \mathrm{C}$.; ii) $\mathrm{MeOH}$, $\mathrm{Na}_{2} \mathrm{CO}_{3} ; 2$ h r.t.; 19; $67.6 \%$. e. $\left(\mathrm{CH}_{3}\right)_{2} \mathrm{SO}_{4} / \mathrm{K}_{2} \mathrm{CO}_{3}$, acetone, r.t.; 10; $60.2 \%$.

Cleavage of the methylenedioxy ring of piperonal to obtain catechol $9(68.4 \%$ yield $)$ was achieved using $\mathrm{TiCl}_{4}$ solution. The absence of the methylenedioxy singlet $6.07 \mathrm{ppm}$ confirmed the presence of catechol, instead two broad signals at $\delta=7.49$ (b.s., $1 \mathrm{H}$ ) and $\delta=7.44$ (b.s., $1 \mathrm{H}$ ) are now observed in ${ }^{1} \mathrm{H}-\mathrm{NMR}$ spectrum.

\section{Biological Results}

These natural compounds used in this study were chosen because they are predominant flavor components of some plants used in the food industry, for this reason, foods fortified with these substances (natural or synthetic derivatives) have a potential role preventing diseases.

The in vitro cytotoxicity evaluation of natural and synthetic compounds 1-24 (see Figure 1 and 2) natural and synthesized indicated that cell viability expressed as $\% v s$. control vehicle (ethanol $0.1 \%$ ) was dose-dependent $(\mu \mathrm{M})$. Doxorubicin was used as positive control in this study $\left(\mathrm{IC}_{50}\right.$ value $\left.<10 \mu \mathrm{M}\right)$. Among $\mathrm{IC}_{50}$ values for compounds 4, 5, 10 and $\mathbf{1 2}$ were the most potent, are summarized in Table 1 known as the micromolar concentration that produces $50 \%$ cell growth inhibition after 72 hours of drug exposure.

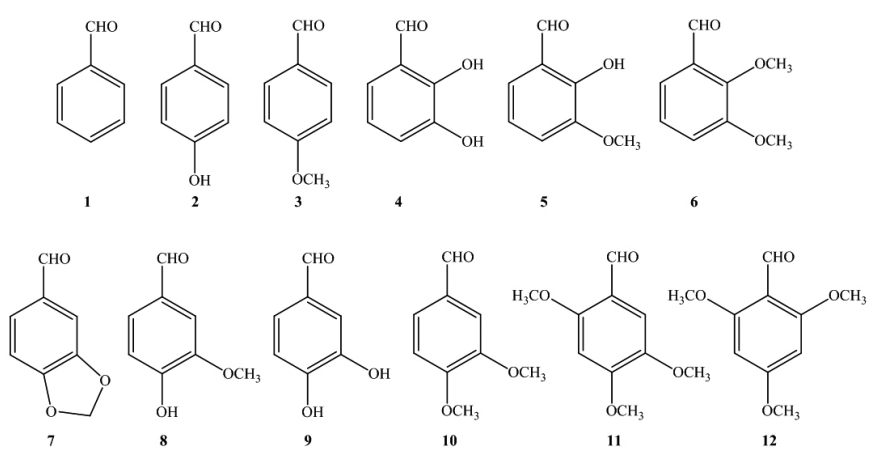

Figure 1. Natural and synthetic Benzaldehydes.

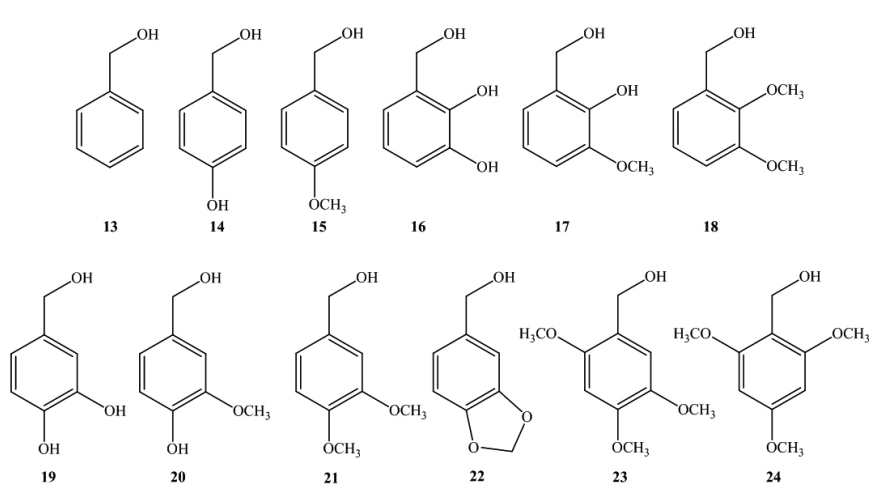

Figure 2. Natural and synthetic Benzyl Alcohols.

We are showing only the biologically active compounds with $\mathrm{IC}_{50}$ lower than $100 \mu \mathrm{M}$, while cytotoxicity exhibited by benzyl alcohols in tested cancer cell lines were higher than $100 \mu \mathrm{M}$. In this preliminary study, the differences in biological activity attributable to the position of the substituents on the aromatic ring are observed for in the different molecules tested.

The cytotoxic effects of vanillin are well known ${ }^{12}$. However, $o$-vanillin was the most active compound in all the cell lines, especially in breast cancer cells MDA-MB231. The structures difference is in the position of the hydroxyl group, therefore $o$-vanillin may generate an intramolecular hydrogen bond, decreasing in polarity and increasing its ability to pass through cell membranes ${ }^{13}$.

On the other hand, the cytotoxic activity of these molecules could be explained by the formation of Schiff bases derived from benzylic aldehydes. Amino groups play an important role in the tertiary structure of cellular enzymes such as tyrosinase, involving the amino group hydrogen bonding which is essential to maintain the tertiary structure of the enzymes ${ }^{14}$. The low conformational stabilities of native proteins make them easily susceptible to denaturation by altering the balance of weak non-covalent bonds that maintain the native conformation. Native proteins form a sort of intramolecular micelle in which the non-polar Schiff base portion is largely out of contact with the water-based environment and the aromatic ring provides stability 
to the system ${ }^{15}$. This would be enhanced in our active compounds due to the presence of electron donor groups $\left(\mathrm{OH}\right.$ and $\left.\mathrm{OCH}_{3}\right)$. Compound 9 has two hydroxyl substituents in position $p$ and $m$ and compound $\mathbf{1 2}$ possesses three methoxy substituents: one in $p$ position and two in $o$ position, which should stabilize the Schiff base and increase cytotoxicity. Thus, the higher activity of compounds $\mathbf{4}$ and $\mathbf{5}$ in comparision to the compounds $\mathbf{9}$ and $\mathbf{1 2}$ is directly related to the existence of intramolecular hydrogen bonding and to proton transfer in the equilibrium ${ }^{16}$. This tautomeric equilibrium has been confirmed, at room temperature by NMR spectroscopic studies ${ }^{17,18}$. Compound $\mathbf{4}$ can form an intramolecular hydrogen bond which would decrease the effect attributed to the tautomerism, therefore $o$-vanillin (compound 5) is the molecule with the highest non-specific cytotoxicity.

Cytotoxicity assays performed by Ho et al. on colon cancer cells HT29 were made in a high concentrations range of $0-10 \mathrm{mM}$ (to $6.58 \mathrm{mM}$ ) for the tested compounds ${ }^{10}$. Unlike Ho's assays, we used a concentration range between 0 and $100 \mu \mathrm{M}$ for all the tested compounds. We obtained an $\mathrm{IC}_{50}$ for vanillin $>100 \mu \mathrm{M}$ on cancer cells HT-29 and an $\mathrm{IC}_{50}=85.10 \pm 6.5 \mu \mathrm{M}$ for $o$-vanillin in the same cell line. Therefore the cytotoxic effect reported by Ho can be explained because the range of concentrations used is some thousand times higher than the concentration we used for this cell line test.

We are reporting the toxicity of $o$-vanillin on prostate cancer cell lines PC-3 and DU-145, calculated $\mathrm{IC}_{50}$ are $47.10+3.8$ and $72.50+5.4 \mu \mathrm{M}$ respectively. However, the highest toxicity was observed against breast cancer cell line MDA-MB231, presenting an $\mathrm{IC}_{50}$ of $35.40 \pm 4.2 \mu \mathrm{M}$, lower than the other tested compounds (for example compound $\mathbf{4}$ has an $\mathrm{IC}_{50}$ of $59.90 \pm 3.9$ $\mu \mathrm{M})$. Compounds $\mathbf{9}$ and $\mathbf{1 2}$ have lower cytotoxic effect in breast cancer cell line, being their $\mathrm{IC}_{50}$ were $82.70 \pm 6.7$ and $78.71 \pm 8.3 \mu \mathrm{M}$ respectively, lower than those presented by compounds $\mathbf{4}$ and $\mathbf{5}$ (See Table 1).

Table 1. Cytotoxic activity $\left(\mathrm{IC}_{50} \mu \mathrm{M}\right)$ of natural and synthetic Benzaldehydes and Benzyl Alcohol derivatives against various human cancer cell lines.

\begin{tabular}{|c|c|c|c|c|c|}
\hline Compounds & Breast MDA-MB231 & Prostate PC-3 & Prostate DU-145 & Colon HT-29 & DHF \\
\hline 4 & $59.90 \pm 3.9$ & $84.15 \pm 8.5$ & - & - & $>100$ \\
\hline 5 & $35.40 \pm 4.2$ & $47.10 \pm 3.8$ & $72.50 \pm 5.4$ & $85.10 \pm 6.5$ & $>100$ \\
\hline 9 & $82.70 \pm 6.7$ & $77.45 \pm 8.97$ & - & - & $42.40 \pm 6.2$ \\
\hline 12 & $78.71 \pm 8.3$ & $71.93 \pm 9.2$ & - & - & $82.40 \pm 9.2$ \\
\hline Doxorubicin & $0.46 \pm 0.06$ & $8.44 \pm 0.05$ & $2.50 \pm 0.04$ & $2.15 \pm 0.02$ & $13.3 \pm 1.80$ \\
\hline
\end{tabular}

\section{CONCLUSIONS}

In chemical synthetic terms, the development of a new method for deprotection of ether compounds with $\mathrm{TiCl}_{4}$ solution was achieved with better performance than that previously reported by our group ${ }^{19}$.

We can conclude that benzyl alcohols showed no significant cytotoxicity in the cancer cell lines tested. Aldehydes $\mathbf{4}$ and $\mathbf{5}$ showed higher cytotoxic activity than $\mathbf{9}$ and $\mathbf{1 2}$ compounds against the selected cancer cell lines. These results indicate that compound $\mathbf{5}$ exerts this cytotoxic and selective effect on all cancer cells lines over a wide concentration range without effects in nontumoral cell line (DHF).

In order to continue with this preliminary work, we will study mechanisms of cell death such as caspase activity and cytochrome c release, triggered by these four compounds 4, 5,9 and 12 .

\section{ACKNOWLEDGMENTS}

The authors thank DGIP of Universidad Técnica Federico Santa María for financing (Project DGIP No 13.11.36, PAC 2010-2012 for A. M. and PIIC 2012 for I.M.), supporting this research.

\section{REFERENCES}

1. Ohta T., Watanabe M., Watanabe K., Shirasu Y. Fd. Chem. Toxic. 24, 51, (1986).

2. Nitoda T., Fan M. D. and Kubo I. Z Naturforsch. 62c, 143, (2007).

3. Falcón J. E., Del Toro G., Alonso Y. Bioquimia. 31, 132, (2006).

4. King A., Shaughnessy D., Murea K., Leszczynsk, J., Ward W., Umbachb D., Xub Z., Ducharmeb D., Taylor J., DeMarini D., Klein C. Mutat. Res. 616, 60, (2007).

5. da Silva A., Buarque C., Brito F., Aurelian L., Macedo L., Malkas L., Hickey R., Lopes D., Noe F., Murakami Y., Silva N., Melo P., Caruso R., Castro N., Costa P. Bioorg. Med. Chem. 10, 2731, (2002).

6. Santos J., Graf U., Reguly M. L., Rodrigues H. Mutat. Res. 444, 355, (1999).

7. Inouye T., Sasaki Y. F., Imanishi H., Watanebe M., Ohta T., Shirasu Y. Mutat Res. 202, 93, (1998).

8. Brown, H. C. and Krishnamurthy, S. Tetrahedron. 35, 567, (1979).

9. Baeza E., Catalán K., Villena J., Carrasco H., Cuellar M., Espinoza L. J. Chil. Chem. Soc. 57, 1219, (2012).

10. Skehan P., Storeng R., Scudiero D., Monks A., McMahon J., Vistica D., Warren J.T., Bokesch H., Kenney S., Boyd M. R. J. Natl. Cancer Inst. 82, 1107, (1990).

11. Vichai V., Kirtikara K. Nat. Protoc. 1, 1112, (2006).
12. Ho K. L., Yazan L., Ismail N., Ismail M. Cancer Epidemiol. 33, 155, (2009).

13. Ashwood V., Field M., Horwell D., Julien-Larose C., Lewthwaite R., McCleary S., Pritchard M., Raphy J., Singh L. J. Med. Chem. 44, 2276, (2001).

14. Hassan M. Pure Appl. Chem. 79, 2277, (2007).

15. Kubo I. and Kinst-Hori I. J. Agric. Food Chem. 46, 1268, (1998).

16. Blonski C., De moissac D., Périé J. and Sygusch J. Biochem. J. 323, 71, (1997).

17. Sharif S., Powell D. R., Schagen D., Steiner T., Toney M. D., Fogle E. and Limbach H. H. Acta Cryst. B62, 480, (2006).

18. Ambroziaka K., Rozwadowskia Z., Dziembowskaa T., Biegb B. J. Mol. Struct. 615, 109, (2002).

19. Madrid A., Espinoza L., Montenegro I., Villena J. and Carrasco H. Molecules 16, 4632, (2011). 